\title{
The Roman introduction and exportation of animals into Tunisia: Linking archaeozoology with textual and iconographic evidence
}

\author{
Mohamed Azaza ${ }^{\mathrm{a}, *}$, Lídia Colominas ${ }^{\mathrm{b}}$ \\ ${ }^{a}$ Universitat Rovira I Virgili, Avinguda Cataluny, 35, 43002 Tarragona, Spain \\ ${ }^{\mathrm{b}}$ Institut Català d'Arqueologia Clàssica. Plaça d'en Rovellat, s/n, 43003 Tarragona, Spain
}

\section{A R T I C L E I N F O}

\section{Keywords:}

Animal trade

Iron Age

Roman period

North Africa

Faunal remains

\begin{abstract}
A B S T R A C T
The Mediterranean basin was the core of the Roman Empire. Large communication networks were constructed and maintained that enabled the trade and distribution of large number of products between distant territories. North Africa, and more specifically Tunisia, was an important trading area. However, little information is available about the animal trade. To characterize this activity and evaluate its economic importance, in this study we examine which species were introduced and exported during the Roman era in Tunisia using archaeozoological data and contextualizing them with written and iconographic sources. This combined approach shows that the Romans were responsible for introducing and exporting numerous animals. We have documented the introduction of commensal animals, such as black rat (Rattus rattus) and house mouse (Mus sp.), wild animals such as fallow deer (Dama dama) and hare (Lepus sp.), and domestic animals such as rabbit (Oryctolagus cuniculus) and cat (Felis catus). At the same time, North Africa supplied Rome with wild beasts such as lions, tigers, bears and camels. We suggest that the animal trade was an important economic activity for Tunisia not only for the export of wild animals but also for the import of animals that were mainly used for social purposes.
\end{abstract}

\section{Introduction}

Archaeological and historical data have shown that since early times people played a fundamental role in the migration of animals in various locations around the world. One of the most active periods began with the creation of the Roman Empire, which promoted connectivity around the Mediterranean Sea as a unique geographical space. This connectivity encouraged the movement and spread of animals that colonized new areas by travelling on human means of transport. Mobility and trade flourished across the Roman provinces and massive quantities of goods were shipped over thousands of kilometres by sea, river and road (Campillo et al., 2018). Archaeological evidence reveals the interconnectivity of the Roman world, as indicated by traded goods such as ceramics, marble and bricks (Rice, 2008). Oil and grain were also traded in large quantities and transported over long distances (Dark, 2007).

During the Roman period, North Africa was one of the main productive areas and a fundamental source of goods for the Empire. The Romans exploited North Africa to maximize the production of agricultural products and supply them to Rome (Bomgardner, 1992). The introduction of wide-spread olive plantations and cereal cultivations increased prosperity in North Africa after its incorporation into the
Mediterranean-wide economic system (Mackendrick, 1980; Raven, 1984). North Africa supplied Rome with products such as corn, oil, wine, legumes, salt-preserved fish, garum, pepper and other spices, herbs, vinegar and honey (Schwartz, 2004; Carandini, 1983; Rice, 2008). Other imported African products included fruits such as gourds and melons, lemons, figs, dates and fumé grapes (Schwartz, 2004). At the same time, many products were recorded at North African ports, thus providing evidence of trade imports during the Imperial period. In Carthage, numerous italic fine wares, Italian Sigillata, bricks, pumice and Spanish amphorae were present during the 2nd century CE (Rice, 2008). North Africa, and more specifically Tunisia, was an important economic trading area in the Mediterranean basin.

In view of the above, in this paper we aim to shed light on another commodity that was traded in Tunisia but that has been scarcely investigated: animals.

We know that a trade in wild animals existed between North Africa and Rome (Keller, 1913; Toynbee, 1973; Bomgardner, 1992; Epplett, 2001; Mackinnon, 2006, 2010; Pigière and Henrotay, 2012). However, little information is available about the importation of animals to North Africa.

In this study, we identify which species were introduced to Tunisia during the Roman period using an archaeozoological approach and

\footnotetext{
* Corresponding author.

E-mail addresses: mohamed.azaza@gmail.com (M. Azaza), lcolominas@icac.cat (L. Colominas).
} 


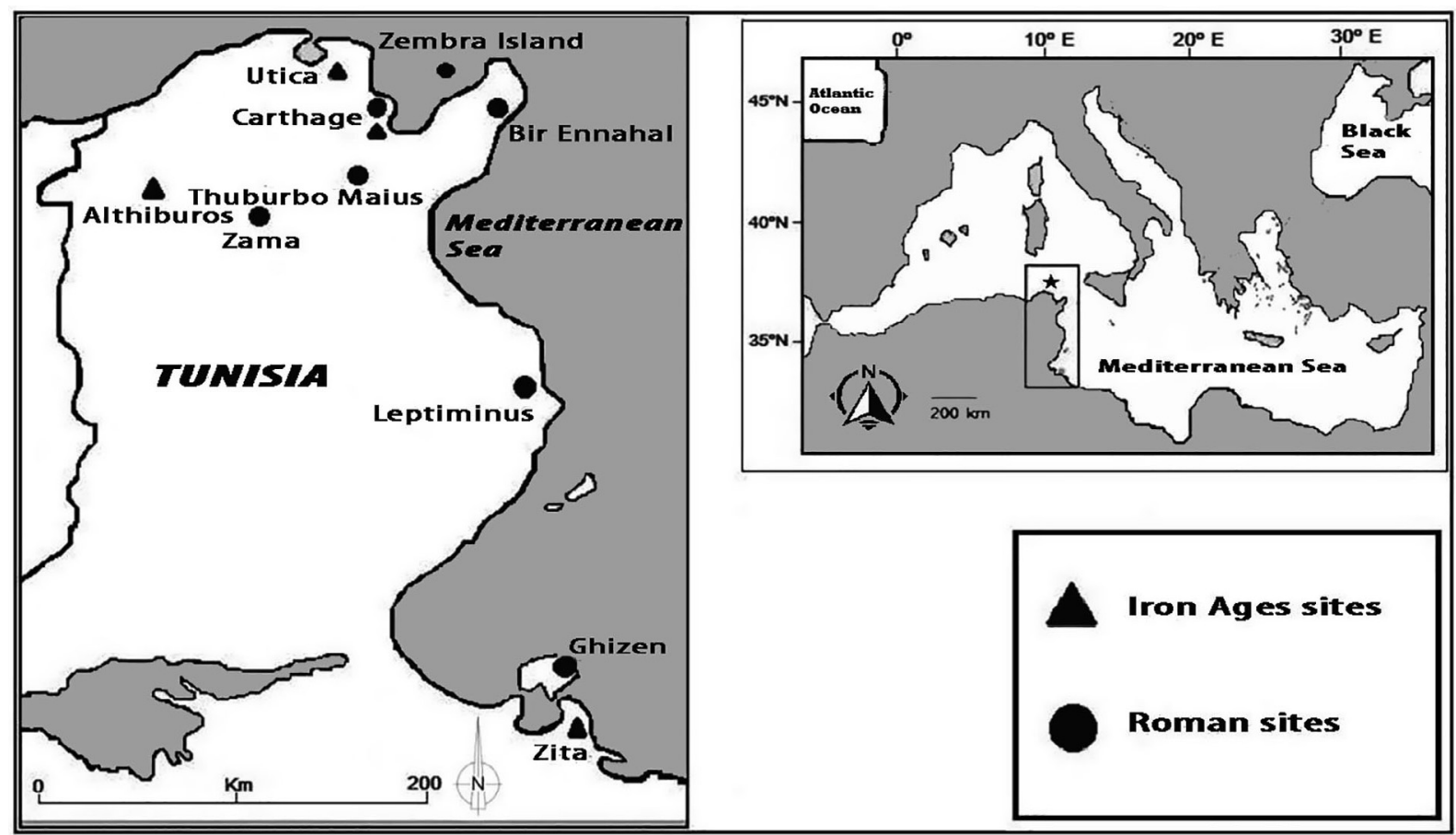

Fig. 1. Location of the Iron Age and Roman Tunisian sites mentioned in the text. For complementary information see Table 1.

compare this information with written and iconographic sources. We also analyse evidence available on the trade of animals from Tunisia to other locations. A review of all the information available on the introduction and exportation of animals is essential to understand the impact and importance of this economic activity in Tunisia during the Roman period.

\section{Material and methods}

To carry out this investigation we have focused on the Roman period but also on the Iron Age. Faunal remains from Iron Age sites will give us an idea about the faunal spectrum before the Roman conquest and it will allow us to contrast the absence/presence of the documented animals in each period. Therefore, our study has centered on the analyses of taxonomic representation of all the species documented (NISP frequency) and in their presence/absence. The available archaeozoological information comes from six Iron Age sites and eight Roman sites (Fig. 1, Table 1).

\subsection{The Iron Age sites}

The Iron Age sites under study here are Utica, Bir Messaouda, Ilot de l'Aumirauté, Magon quarter, Althiburos, and Zita (Fig. 1, Table 1).

The archaeological site of Utica, located in the North of Tunisia (modern day Bizerte), was one of the oldest Tyrian settlements in the Western Mediterranean (Ps. Aristotle, Mir Ausc 134, Flavius Josephus Against Apion I, 18; Velleius Patrerculus I, 2, 3, Plin, Nat. His. XVI, 216 in Cardoso et al., 2016). The Tunisian-Spanish campaigns performed in Utica in 2012-2015 uncovered a very ancient Phoenician architectural complex, $\mathrm{C}^{14}$ dated from the last quarter of the 10th century BCE to the middle of the 9th century BCE (Cardoso et al., 2016). The faunal set recovered in an abandoned water pit was composed by 536 fragments. J. L. Cardoso undertook the study of the faunal material in 2016.

Bir Messaouda site is located in the centre of modern day Carthage. It was an uncultivatable plot appropriated for the construction of the National Court of Cassation. In 1998, an excavation undertaken by the Institut National du Patrimoine de Tunis, and guided by F. Chelbi documented Roman, Late Punic and Archaic structures (Docter, 2002). A project launched by the University of Amsterdam and the Tunisian

Table 1

Archaeological information of Iron Age and Roman sites mentioned in the text. NR = Number of Remains. For complementary information see Fig. 1.

\begin{tabular}{|c|c|c|c|c|c|}
\hline Site & Location & Chronology of the samples & Context of the samples & NR & Reference \\
\hline Utica & Bizerte & 10th-9th c. BC & A water pit & 536 & Cardoso et al., 2016 \\
\hline Bir Messaouda & Carthage & Archaic and Punic periods & buildings & 911 & Slopsma et al. 2009 \\
\hline Ilot de l'Amirauté & & 4th-2th c. BC & Circular Harbour & 131 & Mackinnon, 2010 \\
\hline Magon Quarter & & Second half of the 7th c. BC & Urban structure & 1159 & Nobis, 2000 \\
\hline Althiburos & El Kef & 6th-2th c. BC & Urban structure & 5798 & Valenzuela-Lamas, 2016 \\
\hline Zita & Zarzis & 2nd c. BC-1st c. AD & Urban structure & 1198 & Moses et al. 2019 \\
\hline $\mathrm{Z} 2$ & Zembra Island & 5th-6th c. AD & Terrace of a riverbed & 283 & Vigne, 1988 \\
\hline $\mathrm{Z7}$ «Abri de Casino» & & 2nd/3rd-5th/6th c. AD & Shelter & 352 & Vigne, 1988 \\
\hline Bir Ennahal & Kélibia & 5th c. AD & House (domus) & 766 & Oueslati and Ennaifer, in press \\
\hline Yasmina & Carthage & 2nd-3rd c. AD & Necropolis & 2303 & Mackinnon and Belanger 2006 \\
\hline Kobbat Bent el Rey & & 3rd-5th c. AD & Underground building & 664 & Baumgartner, 1996 \\
\hline Tuburbo Maius & Tunis & Roman period & Courtyard Garden of the House of Bacchus and Ariadne & 34 & Jashemski et al., 1995 \\
\hline Althiburos & El Kef & 1st c. BC- 6 th $^{\text {c. }} \mathrm{AD}$ & Capitolium & 1987 & Valenzuela-Lamas, 2016 \\
\hline Ghizen & Djerba Island & Roman period & Fishermen's houses & 472 & Azaza and Colominas, 2019 \\
\hline Zama & Siliana & 2nd-3rd c. AD & Thermal structure & 367 & Present paper \\
\hline
\end{tabular}


authorities in 2000 continued with the excavations (Docter, 2002). The stratigraphy of the site was divided into nine archaeologically datable periods: two Archaic, two Punic, two Roman, one Vandal, one Byzantine, and one Medieval (Docter, 2002). J. Slopsma was responsible for the processing of the faunal remains, W.Van Neer of the Royal Belgium Institute of Natural Sciences (Belgium) identified fish remains, and L. Karali-Yannacopoulos of the University of Athens studied molluscs (Slopsma et al., 2009). 4850 mammal remains were recovered, and 911 remains were attributed to the Iron Age (Archaic and Punic periods).

Magon Quarter is located on the street of Septime Sévère in modern day Carthage, very close to the sea. It was excavated by the German Archaeological Institute of Rome between 1980 and 1984 directed by F. Rakob. The team documented many different Punic and Roman urban structures, such as the city wall, a handicraft and merchant and housing buildings (Rakob, 1983; Docter, 2002). Faunal remains were studied by G. Nobis (2000).

The Ilôt de l'Amirauté site is a small island inside the Circular Harbour, on modern Carthage. Three periods of occupation have been established on the site by British Archaeologists: an early Punic period, a late Punic period and a Roman period (Hurst, 2008). Trenches and postholes belonged to the 4th century BCE. Ship sheds were built on the island during the early Punic period. The late Punic period can be clearly identified by several buildings (Kruschen, 1978). In Roman times, the Ilot de l'Amirauté became a monumental colonnaded piazza with a temple and octagonal building at its centre (Hurst, 2008). The faunal assemblage comes from the excavations done by the British mission on the site (Mackinnon, 2010).

Althiburos (modern day El Médiena and the ancient Sicca Veneria) is a Numidian and Roman site, located on the Western-North of Tunisia, $215 \mathrm{~km} \mathrm{S-O}$ from Tunis, and $45 \mathrm{~km} \mathrm{~S}$ from el Kef (Kallala et al., 2008). A Tunisian-Spanish project was launched in 2006 between the University of Barcelona and the Institut National du Patrimoine de Tunis, and directed by N. Kallala and J. Sanmarti. 10,379 faunal remains were studied from the excavations carried out between 2006 and 2012 by S. Valenzuela-Lamas. 5798 remains were attributed to the Numidian period (Valenzuela-Lamas, 2016).

The site of Zita, located in South East of Tunisia (modern Zarzis) is an urban site of approximately 34 ha occupied from 500 BCE to $300 \mathrm{CE}$ (Kaufman et al., 2015). An American-Tunisian research project was undertaken by the University of Arizona between 2013 and 2015. The faunal assemblage comes from Area III, Square 1, which corresponds to a domestic area (Moses et al., 2019). 5837 faunal remains were recovered from these campaigns, in which 1198 remains were attributed to the pre-Roman period (Moses et al., 2019).

\subsection{The Roman sites}

The Roman archaeozoological information comes from eight sites: Z2 and Z7 in Zembra Island, Bir Ennahal, Yasmina, Kobbat Bent El Rey, Thuburbo Maius, Leptimus, Althiburos, Zama and Ghizen (Fig. 1, Table 1).

Zembra is an island in the Gulf of Tunis with an area of roughly 340 ha. The outstanding geographic situation, in the entrance of Carthage's golf, and on the road to Sicilia, led to Zembra Island a strategic importance through the history (Chelbi, 2013). Two archaeological campaigns were undertaken by the Centre National de Recherche Scientifique (CNRS) and the Direction Générale de la Santé Tunis (DRST). They were directed by J.D. Vigne in 1986 and 1987 that excavated two trenches: Z2 and Z7 («Abri de Casino») (Vigne, 1988). Z2 has two layers sealed under the ruins of an ancient building. The oldest layer dates from late antiquity (5th-6th century CE). Z7 produced two layers, from which faunal remains were recovered, dating from the 2nd3rd century CE and the 5th-6th century CE respectively. The faunal remains from these two sites were studied by J.D. Vigne (1988), who determined 17 faunal remains from $\mathrm{Z} 2$ and 26 from Z7.
Bir Ennahal is located in the centre of Old Clipea in modern-day Kélibia in the area of Cap Bon (north east of Tunisia). The site was first excavated in 1977, while other investigations were carried out between 1998 and 2000 (Ennaifer, 2002). A large house decorated with many mosaic and hunting scenes was documented. The house was constructed around the middle of the 5th century CE to replace a salt fish factory with tanks for garum dating from the end of the 2nd century or first part of the 3rd century CE (Oueslati and Ennaifer, in press) and it was inhabited until the 7th century CE. The 766 faunal remains recovered from a sewer located under the street along the house were analysed by Oueslati and Ennaifer (in press).

Yasmina, in the southwestern quadrant of the ancient city of Carthage (northern Tunisia), is an early Roman necropolis located in the modern community of Yasmina. It was discovered in 1981 during bulldozing operations for a road that was intended to mark the boundaries of the archaeological zone (Norman and Haeckl, 1993). Five years of excavations were carried out by the University of Georgia with the support of the Tunisian authorities. Inhumation burials from the 2nd century CE, funerary monuments from the early 3rd century CE and cremation burials from the 5th century CE were documented at this necropolis. Little activity has been registered after this date (Norman and Haeckl, 1993). The excavated burial sites yielded various goods and accoutrements, including charred pig remains. One inhumation burial of a young adolescent dated from around the 3rd century CE contained the skeleton of a dog in a relatively complete state (Mackinnon and Belanger, 2006). M. Mackinnon examined the faunal material from Yasmina between 1998 and 1999, while K. Belanger carried out further analyses of the canid remains in 2001(Mackinnon and Belanger, 2006).

Kobbat Bent El Rey, or Baths of Dido, is located in the province of Carthage on Bordj Djdid hill. A vaulted underground building dating from the early 4th century $\mathrm{CE}$, it is considered to be among the bestpreserved residential houses in Carthage. The monument was reconstructed between 1978 and 1989 during UNESCO's international campaigns. The animal bones recovered from excavations of the underground external area were assigned to late antiquity (294-439 CE), Vandal (439-533 CE) and early Byzantine eras (533-695 CE) (Baumgartner, 1996). I. Baungartner conducted her PhD on the study of the Kobbat Bent el Rey assemblage, in which 10.468 faunal remains from at least 122 species were recovered. From this assemblage, 664 faunal remains were attributed to late antiquity (3rd-5th centuries AD) (Baumgartner, 1996).

Thuburbo Maius is located $53 \mathrm{Km}$ southwest of Tunis in the fertile Miliana Valley, which has been famous for its production of grains, olives and fruit since antiquity. Under Hadrian, Thuburbo Maius was a municipium and it became a colony under Commodus (Jashemski et al., 1995). Excavations were undertaken in 1990 by W. F. Jashemski from the Archaeological Institute of America. A total of 34 animal bones were recovered from the Courtyard Garden of the House of Bacchus and Ariadne dated from the 3rd-4th centuries AD and were identified by $\mathrm{H}$. Setzer (Smithsonian Institution) between 1990 and 1995 (Jashemski et al., 1995).

Leptiminus is an ancient Roman city located on the Mediterranean coast of Tunisia in the modern-day town of Lamta, which is $16 \mathrm{Km}$ from Monastir. Excavations were undertaken in the area 304 between 2004 and 2006 by L. Stirling of the University of Manitoba (Canada) and N. ben Lazreg of the Institute National du Patrimoine (Tunisia). The site dates from the 2nd to the 5th century CE (Keenleyside et al., 2009). Faunal remains recovered from the area of the necropolis were studied by M. Mackinnon in 2006. The author did not indicate the total Number of Identified Specimens but identified fish, sheep, goat, hare, cattle, dog, and equid (Keenleyside et al., 2009).

Althiburos site played also a fundamental role as an interconnected city during the Roman period, with an occupation dated to the 1st century BCE until the 6th century CE (Ben Moussa and Calvo, 2016). 1987 faunal remains were recovered from the Roman layers and studied 
by Valenzuela-Lamas (2016).

Zama is located in the plain of Siliana (North West of Tunisia) in the vicinity of the famous battle of Zama. Written sources show that Zama was an important Roman city. Since 1995, numerous surveys have been carried out at the site (Ferjaoui, 2001). A Tunisian-Italian mission was undertaken by the University of Sassari (Italy) and the National Heritage Institute of Tunisia, who in 2002 excavated the thermal structures dating from the 2nd-3rd centuries AD (Bartoloni et al., 2010). The 367 faunal remains from this thermal structure studied so far by M. Azaza are presented in this paper.

Ghizen is located in the northeast of Djerba Island (southern Tunisia). Archaeological excavations on this site led by the National Heritage Institute of Tunisia were conducted between 2008 and 2011 (Bentaher, 2014). These excavations documented a quadrangular space made up of three rooms of similar dimensions (Bentaher, 2014). These rooms presented three levels of occupation dating from the Punic and the Roman periods, although anthropogenic activities since the 6th century BCE have been documented. The presence of several fishing net pondera and hooks indicate that these rooms were fishermen's houses (Bentaher and Sternberg, 2011). A total of $\mathbf{4 7 2}$ faunal remains from the Roman occupation of these fishermen's houses have been studied by M. Azaza (Azaza and Colominas, 2019).

\section{Results}

In this study, animal bones from the Pre-Roman period are from excavations carried out in Utica, Carthage, Althiburos, and Zita. From the Roman period the remains come from Zembra Island, Bir Ennahal, Carthage, Thuburbo Maius, Ghizen and Zama (Table 1).

The faunal remains recovered are mainly mammalian species, in which the majority were domestic animals (Table 2). In this sense, the most common faunal remains in all the sites under study here are those of caprines, cattle, and pigs, as wastes of food. Other domestic animals are also present in the two periods, although their presence is not uniform in all sites. These are equid and dogs. Furthermore, there are other domestic animals only and/or mainly present in the Roman record. These are cats and rabbits. Cat remains have been documented at the Roman sites of Bir Ennahal, Tuburbo Maius and Zama and possibly at Zembra Island (Table 2, Fig. 2). Rabbit remains have been documented at the Roman sites of Zembra Island, Tuburbo Maius, Althiburos and Ghizen (Table 2, Fig. 2). It should be highlighted that 4 rabbit remains were also recovered at the Iron Age phase of Althiburos (Valenzuela-Lamas, 2016).

In relation to wild mammals, their presence is scarce in all sites, but we also document some species present in both periods and others only present in the Roman phase of the sites. The wild mammals present during the Iron Age and Roman period are Barbary lions, foxes, elephants and hares (Table 2). On the contrary, the wild mammals only present during the Roman period are fallow deer, red deer, hedgehog, hare, black rat and house mouse (Table 2, Fig. 3). Fallow deer remains have been documented at the Roman sites of Bir Ennahal and Kobbat Bent El Rey, and red deer at Bir Ennahal. Hedhehog is present at Kobbat Bent El Rey site. Black rat has been documented at the Roman sites of Zembra Island and at Bir Ennahal, and house mouse probably at Zembra Island.

\section{Discussion}

Before starting the discussion, some considerations are important to highlight in relation to methodological issues. First of all, we must point out that although the archaeozoological evidence has been increased in the last years, it remains scarce. For that reason, in this section we discuss the faunal data taking into account the textual and the iconographic evidence as far as possible. Another point to note is that we have accepted as correct the taxonomical identifications of the authors, although in most of the papers (specially the earlier reports), any explanation exists about the criteria used in their determination. We have encountered the same lack of information in relation to taphonomic issues or aspects related to the context of recovery of the samples. In this sense, we cannot be totally sure that none of the faunal remains presented here is intrusive, especially concerning the microfauna, because most of them are faunal reports in which this data is not reported. Although these deficiencies, we think that some general considerations are possible to make, if the data is conjointly evaluated.

\subsection{Introduced animals}

Taking into account the data presented in this study, we propose that the cat, the rabbit and the hare, the house mouse, the black rat and the fallow deer were introduced into Tunisia during the Roman period. Numerous studies have analysed the dispersion of these animals throughout Europe and their place of origin (see for example Vigne, 1988; Hardy et al., 1994; Dobney and Harwood, 1999; Lepetz and Yvinec, 2002; Albarella, 2007; Sykes et al., 2011; Valenzuela et al., 2016), showing that their spread was probably due to the Roman trade. This scenario fits well with the archaeozoological data presented here, in which these animals are only present in some of the Roman sites. Therefore, they were also probably introduced to North Africa in this period.

The dispersal of fallow deer to Europe is attributed to the Romans (Lever, 1977; Whitehead, 1972; Pascal et al., 2006; Sykes et al., 2011; Valenzuela et al., 2016). We suggest that these animals must have also been introduced to western North Africa during this period since live wild fallow deer did not exist in that area before (Kowalski and RzebikKowalska, 1991; Baumgartner, 1996) and five remains have been documented at Bir Ennahal and one remain at Kobbat Bent El Rey. Nevertheless, we should also bear in mind that a trade in fallow deer antlers and metapodials as raw materials for craft activities existed in antiquity (Sykes, 2010). Roman texts also intimate that they were mostly traded for their medicinal properties. According to Pliny the Elder's Natural History, powdered deer antlers could be used to cure a range of disorders from tooth ache to epilepsy (see book XXVII, Trans. Jones 1963 in Madgwick et al., 2013). In Tunisia, fallow deer probably were introduced for hunting purposes linked with a high status activity, as the few identified remains were recovered in residential houses. A hunting mosaic from Le Kef in western Tunisia, dating from the late 2nd century CE should be pointed out, as it depicts a group of ostriches and deer herded into an enclosure by huntsmen (Lavin, 1963).

It has been suggested that the black rat and the house mouse were unwittingly introduced during the Roman period by human movements through maritime shipping routes (Vigne, 1994; Vigne and Villié, 1995; Albarella, 2007). Some recent studies however, show that, at least, the spread of house mouse in the western Mediterranean could be dated to the early 1st millennium cal BC and linked to both Greek and Phoenician maritime activities (Cucchi et al., 2005). The current available data for Tunisia, with the documentation of house mouse at the Roman site of Zembra Island and of black rat at Zembra Island and at Bir Ennahal and not before, could suggest their timid introduction during that period and not before. The introduction of these commensal animals must have been accidental in the wake of human habitation as these animals found refuge in grain depots that would have provided them with ideal habitats. Their introduction, however, was not without cost since it brought concomitant implications for foodstuff storage, hygiene and human health (Dobney and Harwood, 1999).

Domestic cats have been transported all over the world and have invaded mainland and insular systems (Nogales et al., 1996; Vigne et al., 2004; Cross, 2016). It has been suggested that they were introduced to Europe by Greek and Phoenician traders and later by the Romans. The spread of the black rat and the house mouse along sea routes probably encouraged cat dispersal, since this animal is important to human societies as a pest-control agent (Ottoni et al., 2017). Cat remains have been recovered in Roman North African contexts at Bir 
Table 2

Archaeozoological information from Iron Age and Roman Tunisian sites mentioned in the text. NISP = Number of Identified Specimens.

\begin{tabular}{|c|c|c|c|c|c|c|c|c|c|c|c|c|c|c|c|}
\hline \multirow{2}{*}{$\begin{array}{l}\text { Period } \\
\text { SITES }\end{array}$} & \multicolumn{6}{|c|}{ Iron Ages } & \multicolumn{9}{|c|}{ Roman period } \\
\hline & Utica & Bir Messaouda & $\begin{array}{c}\text { Ilot de } \\
\text { l'Amirauté }\end{array}$ & $\begin{array}{l}\text { Magon } \\
\text { Quarter }\end{array}$ & Althiburos & Zita & $\mathrm{Z} 2$ & $\mathrm{Z7}$ & $\begin{array}{c}\text { Bir } \\
\text { Ennahal }\end{array}$ & Yasmina & $\begin{array}{c}\text { Kobbat } \\
\text { Bent El } \\
\text { Rey }\end{array}$ & $\begin{array}{l}\text { Tuburbo } \\
\text { Maius }\end{array}$ & Althiburos & Ghizen & Zama \\
\hline $\begin{array}{c}\text { Ovis aries } \\
\text { (sheep)/Capra } \\
\text { hircus (goat) }\end{array}$ & 142 & 134 & 85 & 448 & 1007 & 39 & & 3 & 62 & 1073 & 85 & 8 & 351 & 57 & 75 \\
\hline $\begin{array}{l}\text { Bos taurus } \\
\text { (cattle) }\end{array}$ & 265 & 75 & 33 & 556 & 523 & 2 & & & 67 & 221 & 8 & & 55 & & 34 \\
\hline Sus sp. (pig) & 88 & 20 & 13 & 155 & 352 & & 1 & 2 & 104 & 1008 & 72 & 5 & 238 & 6 & 11 \\
\hline $\begin{array}{c}\text { Equus sp. } \\
\text { (equid) }\end{array}$ & 24 & 1 & & & 60 & & & & 11 & & 6 & & 11 & 1 & 2 \\
\hline Felis catus (cat) & & & & & & & & $1 ?$ & 1 & & & 1 & & & 1 \\
\hline $\begin{array}{l}\text { Canis familiaris } \\
\text { (dog) }\end{array}$ & 12 & 7 & & & 53 & & & & 3 & 1 & 5 & & 2 & & 1 \\
\hline $\begin{array}{c}\text { Panthera leo } \\
\text { (barbary lion) }\end{array}$ & & 1 & & & & & & & & & & & & & \\
\hline Vulpes sp.(fox) & & & & & & 1 & & & 1 & & & & & & \\
\hline $\begin{array}{l}\text { Dama dama } \\
\text { (fallow deer) }\end{array}$ & & & & & & & & & 5 & & 1 & & & & \\
\hline $\begin{array}{c}\text { Cervus elaphus } \\
\text { (red deer) }\end{array}$ & & & & & & & & & 1 & & & & & & \\
\hline $\begin{array}{c}\text { Erinaceus } \\
\text { algirus } \\
\text { (hedgehog) }\end{array}$ & & & & & & & & & & & 2 & & & & \\
\hline $\begin{array}{l}\text { Oryctolagus } \\
\text { cuniculus } \\
\text { (rabbit) }\end{array}$ & & & & & 4 & & 2 & 12 & & & & 1 & 4 & 1 & \\
\hline Lepus sp. (hare) & & & & & 3 & 2 & & & 5 & & & & 1 & & \\
\hline $\begin{array}{c}\text { Rattus rattus } \\
\text { (black rat) }\end{array}$ & & & & & & & & 4 & 1 & & & & & & \\
\hline $\begin{array}{c}\text { Mus sp. (house } \\
\text { mouse) }\end{array}$ & & & & & & & & $1 ?$ & & & & & & & \\
\hline $\begin{array}{c}\text { Sciurus sp. } \\
\text { (squirrel) }\end{array}$ & & 1 & & & & & & & & & & & & & \\
\hline $\begin{array}{c}\text { Hystrix cristata } \\
\text { (porcupine) }\end{array}$ & & & & & & 1 & & & & & & & & & \\
\hline $\begin{array}{l}\text { Loxodonta } \\
\text { africana } \\
\text { (elephant) }\end{array}$ & 3 & & & & & & & & & & & & 1 & & \\
\hline $\begin{array}{c}\text { Testudo } s p . \\
\text { (tortoise) }\end{array}$ & 2 & & & & & & & & & & & & & & \\
\hline Aves (birds) & & & & & 23 & 8 & 12 & 4 & 143 & & 66 & & 46 & 2 & 2 \\
\hline $\begin{array}{c}\text { Osteichthyes } \\
\text { (fishes) }\end{array}$ & & & & & & 42 & & & 67 & & 13 & & & 5 & \\
\hline $\begin{array}{l}\text { Mollusca } \\
\text { (mollusk) }\end{array}$ & & & & & 7 & 21 & & & 26 & & 241 & & 13 & 1 & 1 \\
\hline $\begin{array}{c}\text { Herpetiles } \\
\text { (amphibians }+ \\
\text { reptiles) }\end{array}$ & & & & & 44 & 1 & & & & & 7 & & 1 & & \\
\hline NISP & 536 & 239 & 131 & 1159 & 2002 & 45 & 17 & 26 & 261 & 2303 & 174 & 15 & 662 & 65 & 12 \\
\hline
\end{tabular}

Ennahal, Tuburbo Maius, Zama and probably at Zembra Island. Through our analysis, it seems that its arrival was also during the Roman period, being present on the coastal sites and on islands of Tunisia and not before, and being more common than its preys. This fact could have been showing that the scarce presence of rat and mouse in the archaeozoological record is due to taphonomic biases.

Rabbits and hares were important sources of hunting game and were not introduced as a supply of meat in antiquity (Baumgartner, 1996). It has been suggested that the Romans introduced the rabbit from the Iberian Peninsula to many territories (Rogers et al., 1994; Dobney and Harwood, 1999), among which we could include North Africa. Several rabbit and hare remains have been documented at Zembra Island, Bir Ennahal, Tuburbo Maius, Ghizen, Althiburos and Leptiminus, which could indicate their introduction and dispersal across the territory. They are also common animals depicted in African mosaics, although their appearance in them is not clearly indicative of their physical presence in the territory. Some examples are the mosaic of Lord Julius of Carthage, dated from the late 4th to the early 5th century CE that depicts a dog as well as a labourer carrying a basket of grapes and holding a rabbit (Parrish, 1979); the mosaic from Althiburos that shows a hare being picked up by its forelegs (Parrish, 1979); the "Satyrs and the Bacchantes" mosaic that depicts a hare (Balmelle et al.,
1990); or the pavement found at El-Jem (Mahdia) and attributed to the 3rd century CE that depicts a rabbit hunting scene with hunters and dogs (Lavin, 1963). If we take into account that North-African mosaicists and patrons were less bound to traditional iconography and composition, which resulted in greater variety, innovative designs and a remarkable realism (Dunbabin, 1978), we could speculate that African pavements could be showing that rabbits and hares were, at least, known animals in North Africa during the Roman period. Nevertheless, four rabbit remains and five of hare were identified in the Numidia phase of Althiburos (Valenzuela-Lamas, 2016) and in Zita (Moses et al., 2019). Any information related to the archaeological context of these findings and about taphonomy is provided. If we take into account these punctual findings, we can point out that, at least, their spread across the territory was during the Roman period and not before.

\subsection{Exported animals}

North Africa was an outstanding platform from which to export African wild animals. The North African provinces of Mauretania, Numidia, and Africanus Proconsularis offered closer sources than Ethiopia for the acquisition of exotic African animals for Rome (Mackinnon, 2006). It has been suggested that the development of this 


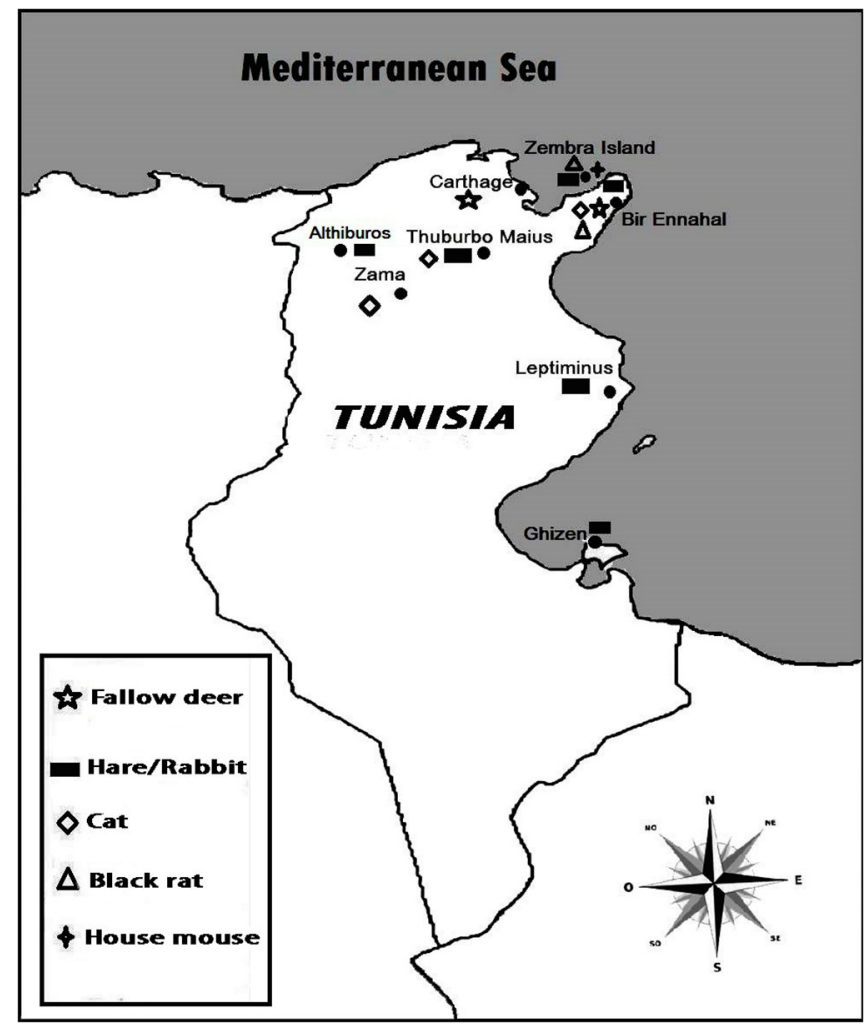

Fig. 2. Distribution of the introduced animals to Tunisia by sites during the Roman period (archaeozoological record).

wild animal trade during the Roman period was due to an increased demand for exotic beasts for entertainment and spectacles (Toynbee, 1973; Mackinnon, 2006). The successful outcome of the Punic wars gave Rome access to a large number of Africanae bestiae. In fact, after the Second Punic war, Rome obtained a secure source of wild animals from North Africa that were destined for the games. As Roman power and influence expanded throughout the Mediterranean, beast-hunts also became popular and spread quickly to other cities. Hundreds of animals from North Africa, including elephants, antelopes, lions, leopards, cheetahs, camels, ostriches, rhinoceros, bears, and giraffes, were used for spectacles (Epplett, 2001). Zebras, tigers, snakes and lynxes are also included in the list of animals collected for these games. Romans, therefore, captured and transported large numbers of North African animals for events staged throughout the Empire.

Potentially exported animals are sporadically represented in the faunal spectrum of Tunisia, but we have documented the local presence of Barbary lions, elephants, foxes and red deer (Table 2, Fig. 3). Archaeozoological evidence for exotic beasts in Roman cities outside North Africa is also scarce but some examples do exist (Fig. 3). Excavations conducted during the 19th and early 20th centuries around the Colosseum in Rome documented the remains of lions, tigers and other exotic animals (Lanciani, 1979: 373, 385; Ghini, 1988). The excavation of a 5th-7th century CE drain at the Meta Sudans site, located roughly $50 \mathrm{~m}$ southwest of the Colosseum, documented 16 bear bones, 2 leopard bones, an ostrich fragment and the remains of several red deer, roe deer, wild boar and foxes (De Grossi Mazzorin, 1995: 309-318).

Mosaics and other art forms described and depicted the capture, transportation and maintenance of these animals before their exhibition. Some examples are the mosaic from Carthage-Dermech dating from the early 4th century CE that depicts the capture of a lioness and caged bear before they were shipped to their ultimate destinations (Epplett, 2001); a cippus found in Tunisia that shows a bull-baiting venator in the air (Epplett, 2001); an early 3rd century mosaic from
Radez (Tunisia) that depicts the scene of a boar hunt (Epplett, 2001); a mosaic from Utica (Tunisia) that depicts the capture of a Berber stag (Keller, 1913); a hunting mosaic from Hippo Regius (Algeria) that shows hunters in pursuit of antelopes (Loisel, 1912; Jennison, 1937); a mosaic from the "Maison de la chasse" in Utica that shows two hunters driving gazelles into a waiting net (Dunbabin, 1978); mosaics found in Carthage and Hippo Regius that illustrate the capture of wild equine (Toynbee, 1996; Dunbabin, 1978; Anderson, 1985); or the "Magerius mosaic" in Smirat (Tunisia) that represents the performance of four leopards and four venatores (Sparreboom, 2016) among others. Mosaics should not always reflect the reality, but the prominence of venatorial themes and the absence of gladiators in African mosaics suggest that in North African Roman period, beast fights attained greater cultural importance than gladiators (Sparreboom, 2016).

Written sources also provide information about the trade of wild North African animals. Pliny the Elder records that elephants could still be obtained in North Africa in the 1st century CE (Nat.His.VII, 11, 32 in Cardoso et al., 2016). Appian records that Scipio Africanus exhibited elephants during his triumphal ceremony for his victory at Zama in 202 BCE (Sparreboom, 2016). Large numbers of Barbary lions (Panthera leo leo) were also caught in North Africa and transported to Rome to be used in the Arena (Slopsma, et al., 2009; Barnett et al., 2008). In the games given by Sella, a Roman patronus, 100 lions supplied by King Bocchus of Mauretania were hunted (Bomgardner, 1992). King Massinissa of Numidia (203-148 BCE) may have supplied many of the animals used in early Roman spectacles (Epplett, 2001). Athenceus tells the story of the Roman gastronome Apicius, who approached the Libyan coast for North African products to supply the city of Rome. Prized birds such as the ostrich and the African chicken (Guinea fowl) were hunted from the desert and transported to Rome (Schwartz, 2004).

The importation of dromedary (Camelus dromedarus) and bactrian (Camelus bacterianus) camels to several provinces of the Roman Empire has also been documented (Fig. 3). Camel bones were found at the Colosseum in Rome (De Grossi Mazzorin et al., 2005), the Roman amphitheatre in Cartago Nova in Spain (Morales Muñiz et al., 1995) and the Roman amphitheatre in Serdica in Bulgaria (Velichkov, 2009: 125). Camels were also imported to the northern provinces of the Roman Empire, such as Austria, England, France, Belgium, Germany, Hungary and Switzerland (Pigière and Henrotay, 2012: 1531-1539; Benecke, 1994, 328; De Grossi Mazzorin, 2006, 234). At Ajdovscina-Casta (Slovenia), four camel teeth were identified in a deposit dated to $270 \mathrm{CE}$. Three camel bones were documented from the site at Hrusica-Ad Pirum (Slovenia) dating from the 3rd century CE, and three elements of camel hindlimbs were found at Vranj (northern Serbia) dating from the 3rd4th century CE (Tomczyk, 2016:1-13).

They were traded from Africa to be used as pack animals linked with both military and civilian traffic (Toynbee, 1973; Pigière and Henrotay, 2012). Pliny the Elder also indicates other uses, writing that camel products, such as the brain, the tail and dung were used in medical and beauty treatments (Vuković-Bogdanović and Blažić, 2014). Meat, milk, fat, hair, wool and leather are other products from dromedaries and bactrian camels that were also used since ancient times (KöllerRollefson, 1991; Potts, 2004). Moreover, camels can produce large quantities of meat and fat. In this context, fragmentation and butchering marks on long bones from the Roman city of Viminacium (Serbia) suggest that camel meat may also have been consumed (VukovićBogdanović and Blažić, 2014). Therefore, these animals could be exported from Tunisia for very different purposes, starting for their power as pack animal but also for the products that could be obtained from them once sacrificed. We also know from historical sources that Emperor Claudius (Dio. LX, 7,3) organized camel fights and that Emperor Nero (Suetonius Nero III) introduced camel races to the Circus Maximus (Toynbee, 1996).

The animal trade between Italy and Africa was organized predominantly by shipping routes. Improved transport mechanisms in relatively peaceful social and political circumstances may have promoted 


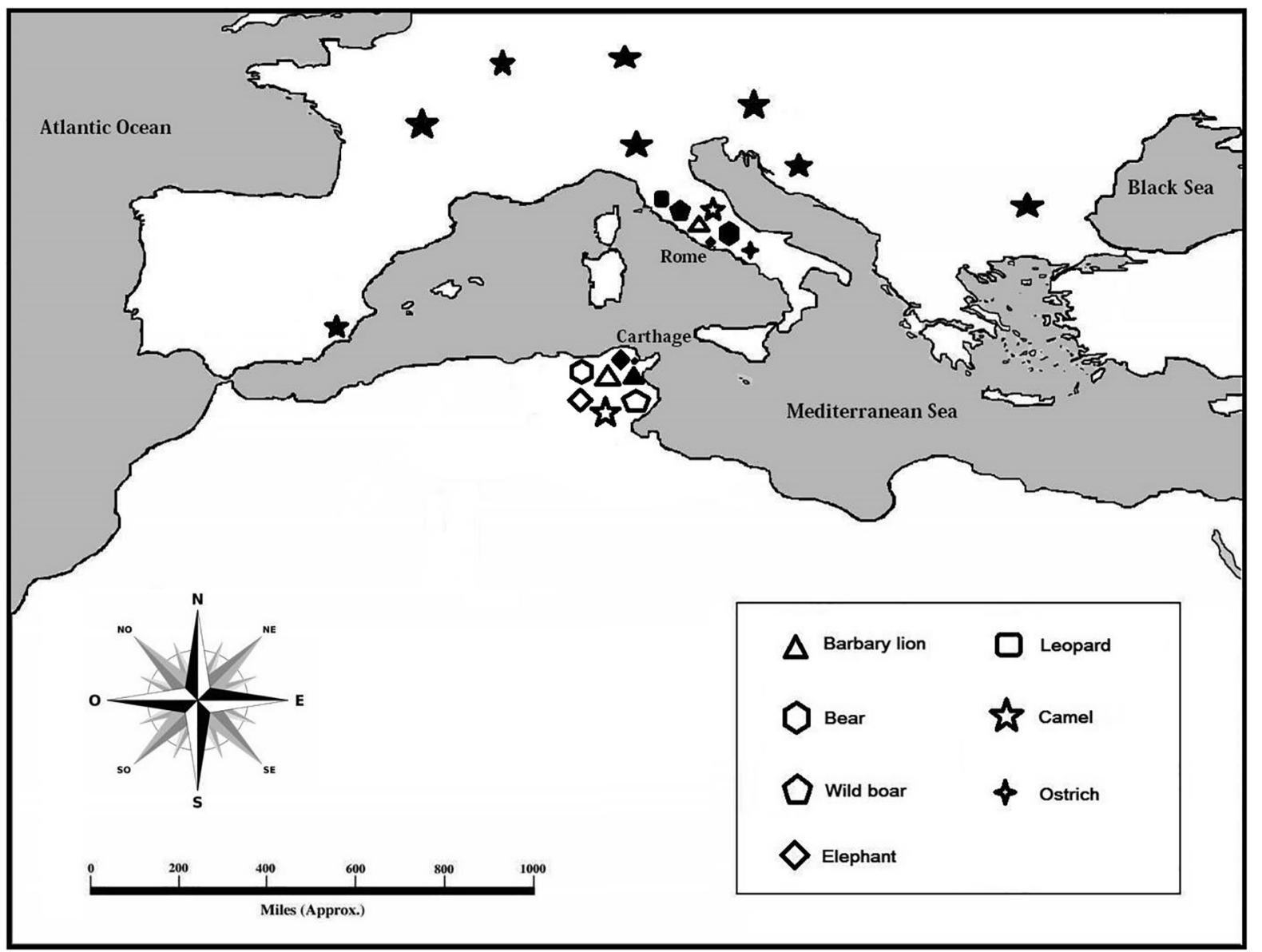

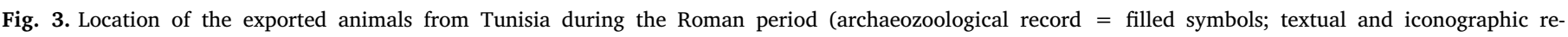
cord $=$ empty symbols).

trading ties to outlying areas (Mackinnon, 2010). In this sense, an Ostian inscription dating from roughly $180-200$ CE records shippers from Hippo Diarrytus in Tunisia, while two other inscriptions from the same site mention exporters from Carthage (Epplett, 2001). Despite the Roman trade, large numbers of lions and leopards survived in Algeria and Morocco until at least the 19th century. Large numbers of ostriches also survived in those countries until the beginning of the 20th century.

\section{Conclusion}

This study presents the first compendium of archaeozoological data about animal Roman trade in Tunisia. We have found some obstacles, such as the, still, scarcity of data, the complicated taxonomical identification of some species and some taphonomic biases. However, current evidence suggests that the Romans were responsible for introducing several animals to Tunisia. We have documented the introduction of commensal animals (black rat, house mouse) as well as the conscious introduction of wild (fallow deer, and hare) and domestic (rabbit and cat) animals.

The introduction of commensal animals such as the black rat and the house mouse must have been accidental. Whereas the conscious introduction of animals indicates their economic and social importance, which were brought to North Africa for specific purposes. In this paper we have demonstrated that most consciously introduced animals (fallow deer, rabbit and hare) were related to hunting activities. The translocation of these animals therefore shows the importance of this activity as a symbol of social status for the population living in North Africa that acquired a Roman lifestyle. At the same time, it shows another cultural connection between Tunisia and Italy.
In this paper we have also presented an update about iconographic and textual data about animal Roman trade. This evidence suggests that the Romans played a fundamental role in the exportation of wild animals despite being rarely found in archaeological Tunisian sites. North Africa, and more specifically Tunisia, was a platform for exporting wild beasts to other Roman territories. The increased demand for wild African animals for exhibition and the entertainment of Roman aristocracy encouraged their trade and exportation to Rome.

Therefore, this paper has demonstrated that animals were another commodity traded in North African ports. The evidence presented here suggests that this trade was an important economic activity for Tunisia, not only for the exportation of wild beasts but also for the importation of wild and domestic animals.

This paper has also shown that multidisciplinarity is an indispensable tool for studying animal trade, a topic too complex to be addressed from only one discipline. Archaeozoological evidence accompanied by written and iconographic sources have allowed us to present a more complete view of this phenomenon. However, further research is needed. More archaeozoological data is required to try to answer important questions related to animals' arrival and spread across Tunisia, such as the reasons behind the presence/absence of some species in some Roman sites. Is this due to social, economical or environmental conditions or is it an archaeological bias? We hope that this paper will help to answer some of these complicated questions in the future.

\section{Acknowledgements}

We would like to thank the following people whose support was 
invaluable during the research and for their encouragement: Prof. Robert Sala of IPHES, Dra. Marta Arzarello of Ferrara University. We are grateful to Laia and Eva of UGAD for the good management of our mission in Tunisia. Thanks are extended to the colleague Chokri Touhiri of National Heritage Institute of Tunisia (INP) for his helping to study the archaeozoological material from Zama site. Thanks are also extended to the reviewers who provided comments that greatly improved the paper. The work was carried with the financial support of European programme of International doctorate in Quaternary and Prehistory scholarship Eramus + (IDQP).

\section{Appendix A. Supplementary data}

Supplementary data to this article can be found online at https:// doi.org/10.1016/j.jasrep.2019.102076.

\section{References}

Albarella, U., 2007. Companions of our travel: the archaeological evidence of animals in exile. In Hartmann, S. (Ed.), Fauna and Flora in the Middle Ages. Studies of the Medieval Environment and Its Impact on the Human Mind, Frankfurt am Main, Verlag Peter Lang, pp. 133-54.

Anderson, J.K., 1985. Hunting in the ancient world. Berkeley.

Azaza, M., Colominas, L., 2019. Romanization and Animal husbandry in Tunisia: demand for wool? Hommes et caprinés: de la montagne à la steppe, de la chasse à l'élevage Humans and caprines: from mountain to steppe, from hunting to husbandry XXXIXe rencontres internationales d'archéologie et d'histoire d'Antibes Sous la direction de Lionel Gourichon, Camille Daujeard, Jean-Philip Brugal Éditions APDCA, Antibes, 2019.

Balmelle, C., Ben Abed-Ben Kheder, A., Ben Osman, W., Darmon, P., Ennaifer, M., Gozlan, S., Hanoune, R., Guimier-Sorbets, A.M., 1990. Recherches franco-tunisiennes sur la mosaïque de l'Afrique antique I. Xenia [monographie]. Publications de l'Ecole Française de Rome. 1990/125.

Barnett, R., Yamaguchi, N., Shapiro, B., Sabin, R., 2008. Ancient DNA analysis indicates the first English lions originated from North Africa. Contrib. Zool. 77 (1), 7-16.

Bartoloni, P., Ferjaoui, A., Abiri, A.K., Ben Nejma, M., Guirguis, M., Mallica, L.L., Pompianu, E., Sebaï, M.,Touihri, C., Unali, A., 2010. Nota preliminare sul settore termale di Zama Regia (Siliana, Tunisia). Elementi structurali e di cultura materiale. L'Africa romana XVIII, Olbia 2008, Roma 2010, pp. 2021-2038.

Baumgartner, I., 1996. Tierrestre aus einem spätantiken Gebäude in Karthago. Inaugural-Dissertation. Zur Erlangung der tiermedizinischen Doktorwürde der Tierärztlichen Fakultät der Ludwig-Maximilians-Universität München. München, 1996.

Ben Moussa, M., Calvo, V.R., 2016. La céramique romaine: contextes, répertoires et typologies. Althiburos II. L'aire du capitole et le nécropole méridionale. Documenta 28, 141-143. Tarragone 2016.

Benecke, N., 1994. Der Mensch und Seine Hautiere. Die Geschichte Einer Jahrtausendalten Beziehung. Theiss Verlag, Stuttgart.

Bentaher, S., Sternberg, M., 2011. La pêche à Jerba à l'époque punique: L'apport de l'archeologie. RIVISTA DI STUDI FENICI. Fondata Da Sabatino Moscati. XXXIX, 1. 2011. PISA - ROMA. Fabrizio serra editore. MMXII.

Bentaher, S., 2014. Hypothèses sur les techniques de pêche utilisées par les habitants du littoral nord nord-est de l'île de Djerba aux périodes punique et romaine, à partir des données archéologiques de Ghizène. Pêches méditerranéennes: Origines et mutations Protohistoire-XXI siècle. KARTHALA. Maison méditerranéenne des Sciences Humaines, 19-35.

Bomgardner, D.L.,1992. The trade in wild beasts for roman spectacles: A green perspective. ANTHROPOZOOLOGICA, 1992, $\mathrm{N}^{\circ} 16$

Campillo, X.R., Montanier, J.M., Rull, G., Bermúdez Lorenzo, J.M., Díaz, J., M., González, J.P., Rodríguez, J.R., 2018. The ecology of Roman trade. Reconstructing provincial connectivity with similarity measures. J. Archaeol. Sci. 92, 37-47.

Carandini, A., 1983. Pottery and the African economy, in Garnsey et al. 1983, 145-162.

Cardoso, J.L., Castro, J.L.L., Ferjaoui, A., Martín, A.M., Hahnmüller, V.M., Ben Jerbania, I., 2016. What the people of Utica (Tunisia) ate at a banquet in the 9th century BCE. Zooarchaeology of a North African early Phoenician settlement. J. Archaeol. Sci. Rep. 8, 314-322.

Chelbi, F., 2013. Zembra et Zembretta (Tunisie "îles Jamour"). Les Aegimures de l'antiquité: recherches archéologiques et historiques. AFRICA XXIII, 61-81.

Cross, C.C., 2016. Spatial ecology and population genetics of cats (Felis catus) living in or near conservation-sensitive areas. Master of Science Department of Zoology University of Otago, Dunedin, New Zealand.

Cucchi, T., Vigne, J.D., Auffray, J.C., 2005. First occurrence of the house mouse (Mus musculus domesticus Schwarz \& Schwarz, 1943) in the Western Mediterranean: a zooarchaeological revision of subfossil occurrences. Biol. J. Linn. Soc. 84, 429-445.

Dark, K.R., 2007. Globalizing Late Antiquity. Models, metaphors and the realities of longdistance trade and diplomacy, in A. Harris (ed.) Incipient Globalization (BAR Int. Series 1644, Oxford, 2007).

De Grossi Mazzorin, J., 1995. "La fauna rinvenuta nell'area della Meta Sudans nel quadro evolutivo degli animali domestici in Italia", in Atti del $1^{\circ}$ Convegno Nazionale di Archeozoologia. Rovigo. 309-318.
De Grossi Mazzorin, J., Minniti, C., Rea, R., 2005. De ossibus in anphitheatro Flavio effossis: 110 anni dopo i rinvenimenti di Francesco Luzj, in Malerba G. \& Visentini P. (eds), Atti del $4^{\circ}$ Convegno Nazionale di Archeozoologia, Pordenone, 13-15 novembre 2003. Quaderni del Museo Archeologico del Friuli Occidentale 6. Comune di Pordenone, Museo Archeologico, Pordenone, pp. 337-348.

De Grossi Mazzorin, J., 2006. Camelli nell'antichità: le presenza in Italia. In: Sala, B., Tecchiati, U. (Eds.), Archaeozoological Studies in Honour of Alfredo Riedel, Bolzano, pp. 231-242.

Dobney, T., Harwood, J., 1999. Here to stay? Archaeological evidence for the introduction of comensal and economically importante mammalsm to the North of England. In: Benecke, N. (Ed.), The Holocene History of the Europeam Vertebrate Fauna. Berlin, pp. 373-387.

Docter, R., 2002. Carthage Bir Messaouda: Excavations by the Universiteit VAN AMSTERDAM (UVA) IN 2002 AND 2001 (1). Cedac Carthage. Centre d'Etudes de Documentation Archéologique de la conservation de Carthage. Bulletin 21/Juin 2002, pp. 29-34.

Dunbabin, K.M.D., 1978. The Mosaics of Roman of North Africa: Studies in Iconography and Patronage. Oxford.

Ennaïfer, M., 2002. La chronologie de la maison des deux chasses à Kélibia. Na, Tar., 10, pp. 223-232 (L'Afrique vandale et byzantine. 1ère partie. Monographies régionales).

Epplett, W.C., 2001. Animal Spectacula of the Roman Empire. The University of British Columbia. October 2001.

Ferjaoui, A., 2001. Recherches archéologiques et toponymiques sur le site de Jama et dans ses alentours. In: Comptes rendus des séances de l'Académie des Inscriptions et Belles-Lettres, 145e année, N. 2, pp. 837-864.

Ghini, G., 1988. "Prime indagini archeologiche". In: Reggiani, A.M. (Ed.), Anfiteatro Flavio: Immagini, testimonianze, spettacoli, Rome, pp. 100-105.

Hardy, C., Vigne, J.D., Casañe, D., Dennebouy, N., Mounolou, J.C., Monnerot, M., 1994. Origin of European rabbit (Oryctolagus cuniculus) in a Mediterranean Island: Zooarchaeology and ancient DNA examination. J. Evol. Biol. 7, 217-226.

Hurst, H. 2008. Understanding Carthage as a Roman Port. ROMA 2008. International Congress of Classical Archaeology. Meetings between cultures in the ancient Mediterranean. Bollettino di Archeologia on line I 2010/ Volume speciale B / B7 / 6

Jashemski, W.F., Foss, J.E., Lewis, R.J., Timpson, M.E., Lee, S.Y., 1995. Am. J. Archaeol. 99 (4), 559-576.

Jennison, G. 1937. Animals for show and pleasure in ancient Rome. Manchester.

Kallala, N., Sanmartí, J., Belarte, M.C., Ramón, J., Alvarez, R., Ben Moussa, M., Bechrifiya, S., Bermúdez, X., Campillo, J., Chebbi, N., Fadrique, T., Jornet, R. y D., Bel Haj Nasr Loum, Z., Maraoui, B., Miniaoui, S., Noguera, J., Puche, J.M., Revilla, V., Tarradell, N., Torchani, M., Valenzuela, S., 2008. Recherches sur l'occupation d'Althiburos (région du Kef, Tunisie) et de ses environs à l'époque numide, Pyrenae, 39 (1), 67-113.

Kaufman, B., Drine, A., Barnard, H., Khedher, R., 2015. Research at the ancient Neo-Punic City of Zita, Tunisia. Backdirt Ann. Rev. Cotsen Inst. Archaeol. 76-79.

Keenleyside, A., Schwarcz, H., Stirling, L., Ben Lazreg, N., 2009. J. Archaeol. Sci. 36, 51-63.

Keller, O.,1913. Die antike Tierwelt. 2 vols. Leipzig.

Köller-Rollefson, I., 1991. Camelus dromedarius. Mamm. Species 375, 1-8.

Kowalski, K., Rzebik-Kowalska, B., 1991. Mammals of Algeria. Polish Academy of Science, Wroclaw.

Kruschen, K.H., 1978. The Harbours of Carthage and a Graphic Reconstruction of 2nd Century A.D. Buildings at the Ilot de L'Amirauté. Master thesis. Wilfrid Laurier University.

Lanciani, R., 1979 (reprint edition of 1897). The Ruins and Excavations of Ancient Rome, New York.

Lavin, I., 1963. The hunting mosaics of antioch and their sources a study of compositional principles in the development of early mediaeval style. Dumbarton Oaks Papers, XVII, pp. 179-286.

Lepetz, S., Yvinec, J.H., 2002. Présence d'espèces animals d'origen méditerranéenne en France du nord aux périodes romaine et medieval: actions anthropiques et mouvements naturels. In A. Gardeisen (ed.) Mouvements ou déplacements de populations animals en Méditerranée au cours de l'Holocène. BAR International Serie, 1017, pp. 33-45.

Lever, C., 1977. The Naturalized Animal of Britain and Ireland.

Loisel, G., 1912. Histoire des ménageries de l'antiquité à nos jours, Paris.

Mackendrick, P., 1980. The North African Stones Speak, University of North Carolina Press, Chapel Hill.

Mackinnon, M., 2006. Supplying exotic animals for the roman amphitheatre games: new reconstructions combining archaeological, ancient textual, historical and ethnographic data. Mouseion, Series III 6 (2006).

Mackinnon, M., Belanger, K., 2006. In sickness and in health: care for an arthritic Maltese dof from the Roman cemetery of Yasmina, Carthage, Tunisia. In: Snyder, L.M. Moore, E.A. (Eds.), Dogs and People in Social, Working, Economic or Symbolic Interaction, Oxbow, Oxford, pp. 38-43.

Mackinnon, M., 2010. "Romanizing" Ancient Carthage: Evidence from Zooarchaeological Remains. Zooarchaeology and Colonialism.

Madgwick, R., Sykes, N., Miller, H., Symmons, R., Morris, J., Lamb, L., 2013. Fallow deer (Dama dama dama) management in Roman South-East Britain. Archaeol Anthropol Sci.

Morales Muñiz, A., Cereijo Pecharromán, M.A., Hernández Carrasquilla, F., Liseau Von Lettow-Vorbeck, C., 1995. Of mice and sparrows: comensal faunas from the Iberian Iron Age in the Duero Valley (central Spain). Int. J. Osteoarchaeol. 5, 127-138.

Moses, V., Kaufman, B., Drine, A., Barnard, H., Bentahar, S., Jerray, E., Daniels, M., 2019. Zooarchaeological evidence for meat consumption at Zita, Tunisia, during the Punic to Roman occupations (2nd century BCE to 3rd century CE). Int J Osteoarchaeol. $1-11$. 
Nobis, G., 2000. Die Tierrestre von Karthago, in: F. Rakob (ed.), Khartago vol.III. Die Deutschen Ausgrabungen in Karthago: 574-632. Mainz am Rheim, Verlal Philip von Zabern.

Nogales, M., Medina, F.M., Valido, A., 1996. Indirect seed dispersal by the feral cats Felis catus in island ecosystems (Canary Islands). ECOGRAPHY 19: 3-6. Copenhagen 1996.

Norman, N., Haeckl, A., 1993. The yasmina necropolis at Carthage, 1992. J. Roman Archaeol. 6, 238-250.

Ottoni, C., Van Neer, W., De Cupere, B., Daligault, J., Guimaraes, S., Peters, J., Spassov, N., Prendergast, M.E., Boivin, N., Muñiz, A.M., Bălăsescu, A., Becker, C., Benecke, N., Boroneant, A., Buitenhuis, H., Chahoud, J., Crowther, A., Llorente, L., Manaseryan, N., Monchot, H., Onar, V., Osypińska, M., Putelat, O., Morales, E.M.Q., Studer, J., Wierer, U., Decorte, R., Grange, T., Geigl, E.M., 2017. Research article, Biological Sciences - Anthropology, Genetics Of cats and men: The paleogenetic history of the dispersal of cats in the ancient world. Published: 19 June 2017 | VOL.1 | Article Number: 0139.

Oueslati, T., Ennaifer, M. In press. La Maison des deux Chasses (Kélibia, Tunisie): Approche croisée de l'étude des tbleaux de vénerie et des ossements animaux (VIedébut VIIe s.). In: Blanc - Bijon, V. (Ed.), Actes du coloque «Hommes et animaux au Maghreb de la Préhistoire au Moyen - Âge: exploitations d'une relation complexe», Marseille, Aix-en-Provence, SEMPAM.

Parrish, D., 1979. Two Mosaics from Roman Tunisia: An African Variation of the Season Theme Author(s): David Parrish Source: Am. J. Archaeol. 83 (3) (Jul., 1979), 279-285.

Pascal, M., Lorvelec, O., Vigne, J.D., 2006. Invasions Biologiques et Extinctions; 11000 ans d'Histoire des Vertébrés en France. Paris; Berlin; Versailles: Quae.

Pigière, F., Henrotay, D., 2012. Camels in the northern provinces of the Roman Empire. J. Archaeol. Sci. 39 (2012), 1531-1539.

Potts, D.T., 2004. Camel Hybridization and the Role of Camelus bactrianus in the Ancient Near East. J. Econ. Soc. History Orient 47 (2), 143-165.

Rakob, F.,1983. Brefs Rapports Archéologiques (Allemagne). Cedac Carthage. Centre d'Etudes et de Documentation Archéologique de la Conservation de Carthage. Bulletin 5, Juin 1983.

Raven, S., 1984. Rome in Africa, new ed. Longman, London.

Rice, C., 2008. Southern Mediterranean Port Cities as Microcosms of Connectivity. Bollettino Di Archeologia on Line. Roma 2008. International Congress of Classical Archaeology. Meeting between cultures in the Ancient Mediterranean.

Rogers, P.M., Arthur, C.P., Soriguer, R.C., 1994. The rabbit in continental Europe. Spanish Nat. Res. Counc.

Schwartz, K., 2004. All Roads Led to Rome: Roman Food Production in North Africa
Repast Volume XX, N 4 Fall 200.

Slopsma, J., Van Wijngaarden-Bakker, L., Maliepaard, R., 2009. Animal remains from the bir messaouda excavations 2000/2001 and other carthaginian settlement contexts. Carthage Studies, Gent 2009, 21-63.

Sparreboom, A., 2016. Venationes Africanae: Hunting spectacles in Roman North Africa: cultural significance and social function. University of Amsterdam.

Sykes, N., Baker, K.H., Carden, R.F., Higham, T.F.G., Hoelzel, A.R., Stevens, R.E., 2011. New evidence for the establishment and management of the European fallow deer (Dama dama dama) in Roman Britain. J. Archaeol. Sci. 38 (2011), 156-165.

Sykes, N., 2010. Fallow deer. In: O'Connor, T., Sykes, N. (Eds.), Extinctions and Invasions: A Social History of British Fauna, Windgather Press, Oxford, pp. 51-58.

Tomczyk, W., 2016. Camels on the Northeastern Frontier of the Roman Empire. Inst. Archaeol. 26 (1): Art. 2, pp. 1-13.

Toynbee, J.M.C., 1973. Animals in Roman Life and Art. Thames and Hudson, New York. Toynbee, J.M.C., 1996. Animal in Roman Life and Art. London.

Valenzuela, A., Baker, K., Carden, R., Evans, J., Higham, T., Hoelzel, R., Lamb, A., Madgwick, R., Miller, H., Alcover, J.A., Cau, M.A., Sykes, N., 2016. Both introduced and extint: the fallow deer of Roman Mallorca. J. Archaeol. Sci. Rep. 9, 168-177.

Valenzuela Lamas S., 2016. Alimentation et élevage à partir des restes fauniques. Althiburos II. L'aire du capitole et le nécropole méridionale. Documenta 28, 421-448. Tarragone 2016.

Velichkov, Z., 2009. The amphitheatre of Serdica (City of Sofia Bulgaria). In: Wilmott, T. (Ed.), Roman Amphitheatres and Spectacula: a 21st Century Perspective. BAR International Series 1946. Archaeopress, Oxford, pp. 119-125.

Vigne, J. D., Villié, P.1995. Une prevue archéologiue du transport d'animaux par bateau: le crâne de rat surmulot (Rattus norvegicus) de l'épave du "ça ira" (Saint-Florent, Haute-Corse- fin du XVIIIe siècle). Pages 411-416 in R. Chenorkian, editor. L'Homme méditerranéen. Publications de l'Université de Provence, Aix-en-Provence, France.

Vigne, J.D., Guilaine, J., Debue, K., Haye, L., Gerard, P., 2004. Early taming of the cat in Cyprus. Science 80 (304), 259.

Vigne, J.D., 1988. Données preliminaries sur l'histoire du peuplement mammalien de l'îlot de Zembra (Tunisie). Mammalia, t.52, n4, 1988, pp. 567-573.

Vigne, J.D., 1994. L'île Lavezzi. Hommes, animaux, archéologie et marginalité (XIIIe-XXe siècles, Bonifacio, Corse). Monographie 13 (Centre National de la Recherche Scientifiue). Sophia-Antipolis, France.

Vuković-Bogdanović, S., Blažić, S., 2014. Camels from Roman Imperial sites in Serbia. Anthropozoologica 49 (2), 281-295.

Whitehead, G.K., 1972. Deer of the World. London, Constable. 